\title{
Thermal environment characterization of laying hen-housing systems
}

\author{
Nágela Maria Henrique Mascarenhas ${ }^{a *}$ (D) Dermeval Araújo Furtado ${ }^{(i D}$ | Bonifácio Benício de

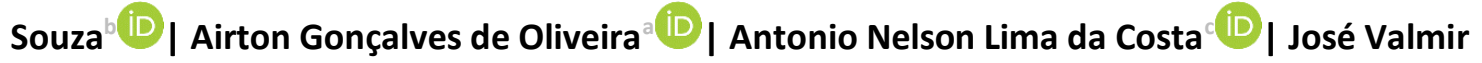

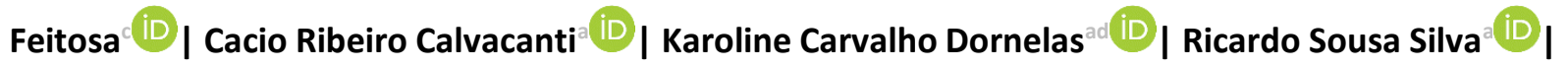 \\ Raimundo Calixto Martins Rodrigues \\ aPostgraduate Program in Agricultural Engineering, Federal University of Campina Grande (UFCG), Rua Aprígio Veloso, 882 - Universitário, Campina Grande, PB, \\ 58429-900, Brazil. \\ ${ }^{b}$ Postgraduate Program in Veterinary Medicine, Federal University of Campina Grande (UFCG), Avenue Universitária, s/n - Santa Cecilia, Patos, PB, 58708-110, \\ Brazil. \\ 'Federal University of the Cariri (UFCA), Road Vereador Sebastião Maciel Lopes, s/n, São José, Crato, CE, 63133-610, Brazil. \\ ${ }^{d}$ Federal University of the Mato Grosso (UFMT), Avenue Alexandre Ferronato, 1200 - Res. Cidade Jardim, Sinop, MT, 78550-728, Brazil.
}

*Corresponding author: eng.nagelamaria@gmail.com

\begin{abstract}
This study systematically collected data on variables that influence the thermal environment characteristics in poultry houses. Laying poultry farming is a relevant economic activity in Brazilian agriculture and has been expressively growing mainly regarding genetics and nutrition. Thermal comfort in poultry houses is needed to achieve poultry's maximum productive potential. Therefore, laying aviaries previously naturally ventilated (positive pressure) are starting to be equipped with cage batteries and designed with lateral closures, using negative pressure ventilation and in some cases associated with adiabatic cooling. However, negative pressure ventilation systems' thermal efficiency in tunnel mode and its distribution in different cage levels is still slightly known. Consequently, this system's thermal efficiency needs to be investigated to ensure adequate climate indices recommendations and avoid costs and losses due to inadequate handling and facilities.
\end{abstract}

Keywords: ambience, heat stress, laying hens, poultry sheds

\section{Introduction}

Laying poultry farming is one of Brazilian agriculture's most relevant economic activities. The success of poultry production depends on reducing climate effects on animals, among other factors (nutrition, sanitary management, among others) (Coelho 2018; Mascarenhas et al 2018).

The system for raising laying hens in Brazil is predominantly (90\%) intensive (Humane Society International 2014), with open facilities equipped with a battery system in conventional superimposed cages with one to eight floors (Coelho 2018). Although the system presents a good economic return, its architectural design can lead to poultry thermal stress due to temperature variations along the installation length and width (Mendes 2015). Therefore, the environmental conditions inside the sheds need to be controlled according to thermal comfort conditions, adopting innovative architectural concepts and managements, and allying the thermal conditioning systems to the local weather conditions (Hu et al 2017).

Birds are homeothermic animals and consequently susceptible to environmental variations. The comfort zone recommended by the literature is divided according to their age, ranging from $35{ }^{\circ} \mathrm{C}$ (hatching) to approximately $24{ }^{\circ} \mathrm{C}$ (adults). Therefore, birds require behavioral, physiological, or anatomical adjustments to adapt to new environmental conditions when exposed to temperatures different from their comfort zone (Andrade 2017).

The main environmental factors that affect bird performance are air temperature, humidity, radiation, and wind speed (El-Kholy et al 2017). High air temperatures and humidity inside the sheds can limit their productive performance and welfare, decline their immune system, and decrease egg quality (Morais et al 2020; Bilal et al 2021).

The focus on animal interaction and the environment was intensified in the sector to achieve a satisfactory production by providing an environment that contributes to the expression of its maximum productive potential. Therefore, laying aviaries equipped with batteries in cages with natural ventilation (positive pressure) started to be designed with lateral closures using negative pressure ventilation and, in some cases, associated with adiabatic cooling.

However, studies describing the thermal environment of laying aviaries in Brazil are still scarce. Therefore, this study systematically collected data on the themes' variables through a vast bibliographical review.

\section{Homeothermy and birds}


The animal welfare concept is characterized as the state of complete physical and mental health in harmony with the environment in which it inhabits. When birds are subjected to thermal stress (cold or heat), they seek to maintain their homeostasis (Saeed et al 2019; Mascarenhas et al 2018).

Birds can maintain their body temperature throughout the year because they are homeothermic animals (Saeed et al 2019). However, thermoregulatory mechanisms are only effective in thermoneutral zones $\left(27.5\right.$ to $37.7^{\circ} \mathrm{C}$ ) (Scanes 2015). The general characteristics of thermoregulation in birds are similar to those in other animals. Nevertheless, birds also use plumage, fat isolation, and salt glands (Scanes 2015).

Furthermore, birds can regulate body temperature using the heat generated in their bodies, comparable to endothermic animals (Melo et al 2016). Variations within and beyond this temperature range may be due to certain physiological conditions (sex, physiological activity, race, age, body weight, molting period, cuttlefish), feeding state (body temperature increases during feed digestion), and the external environment (Farag and Alagawany 2018).

Among the environmental factors, thermal factors (air temperature, relative humidity, solar radiation, and wind speed) are the ones that most affect birds. Thermal factors can impair their vital functions (maintaining their homeotherm), obtained through sensitive and latent heat (Silva et al 2017). Therefore, facilities must provide a thermally comfortable environment for birds (Reis and Freitas 2020).

\section{Thermal and environmental requirements for laying hens}

Birds behave like a thermodynamic system, constantly exchanging energy with the environment. Therefore, the external environment directly influences the internal changes in their organisms, leading to physiological adjustments that act directly and immediately on their behavioral, productive, and reproductive responses (Baêta and Souza, 2010; Mendes, 2015).

Thermoneutrality is achieved under thermal comfort conditions, where the energy given off by the animal to maintain homeothermy is minimal, and there is no interference in production (Andrade 2017; Saeed et al 2019). Therefore, recognizing the critical threshold of superior and inferior temperatures is crucial because the birds activate their thermoregulatory mechanisms in this range.

In conventional systems (cages), birds can have their metabolism modified by several factors, highlighting thermal stress situations, more energetic formulation of the feed provided, or larger food intake (increasing the production of metabolic heat). Together, these factors contribute to an imbalance in the thermoregulatory system (Melo et al 2016; Tan and Knight 2018). In addition to these factors, the use of lamps and motors, birds metabolism, thermal radiation from the roof, and use of side curtains are extra sources of heat energy inside the poultry houses (Huang 2017), resulting in a hostile environment for birds.
Environments with high relative humidity tend to keep excreta moist, providing conditions for pathogenic microorganisms proliferation and making waste removal difficult in facilities equipped with mats (Chen et al 2015). On the other hand, environments with low relative humidity (lower than $30 \%$ ) lead to excessive dust production, resulting in many microorganisms suspended in the air and considerably increasing the emergence of respiratory diseases in birds and workers (Mendes 2015).

Birds' average body temperature is between 41 and $42{ }^{\circ} \mathrm{C}$ (Nazareno et al 2009). Therefore, their thermoregulatory capacity to cold is higher than their capacity to react to heat (Farag and Alagawany 2018). The lower limit of the comfort zone for adult birds is generally 12 ${ }^{\circ} \mathrm{C}$, which is $30{ }^{\circ} \mathrm{C}$ below their body temperature. In comparison, the upper limit is approximately $47^{\circ} \mathrm{C}$, which is only $5{ }^{\circ} \mathrm{C}$ above their body temperature.

The main heat dissipation mechanism in birds is respiratory evaporation once they do not have sweat glands. In a comfortable environment, breathing eliminates around $8 \%$ of the heat produced, while under environmental conditions above the thermal comfort zone $\left(35^{\circ} \mathrm{C}\right)$, breathing eliminates $40 \%$ ( $\mathrm{He}$ et al 2019). Excessive use of the respiratory mechanism for heat loss can cause serious problems. The increase in respiratory rate can generate endogenous heat and, instead of dissipating heat, birds would be depositing more heat inside their body.

In addition to raising the caloric increase within birds' bodies, another serious consequence of the increase in respiratory frequency is acid-base imbalance. Excessive ventilation results in the high-level elimination of carbon dioxide $\left(\mathrm{CO}_{2}\right)$, which is the final product of carbohydrates, lipids, and proteins oxidation. $\mathrm{CO}_{2}$ reacts with $\mathrm{H}_{2} \mathrm{O}$ under the enzymatic action of carbonic anhydrase, forming carbonic acid $\left(\mathrm{H}_{2} \mathrm{CO}_{3}\right) . \mathrm{H}_{2} \mathrm{CO}_{3}$ is an essential blood $\mathrm{pH}$ buffer; therefore, low $\mathrm{CO}_{2}$ concentration decreases $\mathrm{H}_{2} \mathrm{CO}_{3}$ concentration, resulting in alkalosis (increase in blood pH) (Abbas et al 2017; He et al 2019).

Egg production is directly affected by alkalosis because alkalosis reduces the concentration of diffusible or free calcium used for shell formation. Consequently, this mineral imbalance can result in small, thin-shelled eggs (Abbas et al 2017). Birds' responses to heat stress were outlined by Borges et al. (2003), as shown in Figure 1.

\section{Housing for laying hens}

Brazil is the seventh-largest egg producer globally and the largest producer in South America, where it holds 55\% of all production (Avicultura Industrial 2016). Approximately $90 \%$ of laying birds are housed in battery cage systems (Humane Society International 2014) in Brazil because of their good economic return.

Initially, cages were used individually to check daily egg production, facilitating the disposal of unproductive animals. However, birds with high productivity emerged due to genetic advancement, enabling production at high densities (Mendes 2015). Accordingly, manual work was 
reduced due to the automation of poultry sheds, allowing to house more birds per area using up to eight levels of overlapping cages (Yousaf et al 2019).

In battery cage systems, the disposition can occur in several ways (Figure 02), aiming to facilitate activity management. The aviaries are rectangular (varied dimensions), open with or without automation (Telatin Jr 2007).

However, the use of cages receives several criticisms, mainly due to the limited space and high density, which restrict the natural behavior of birds, causing discomfort and stress. In addition to the high incidence of problems in birds' bone structure (Shields and Duncan 2008), cages contribute to problems in their feet due to the cage's floor.

Some authors advocate the use of litter and nests (Pereira et al 2013; Chen et al 2015), where the bird can better express its natural behavior, considerably reducing stress. Due to the foreign market requirements, laying poultry is increasingly competitive with an intensification in nesting systems use, aiming to meet the fifth freedom, allowing the bird to express its natural behavior, and improving the laying performance (Barbosa Filho et al 2007).

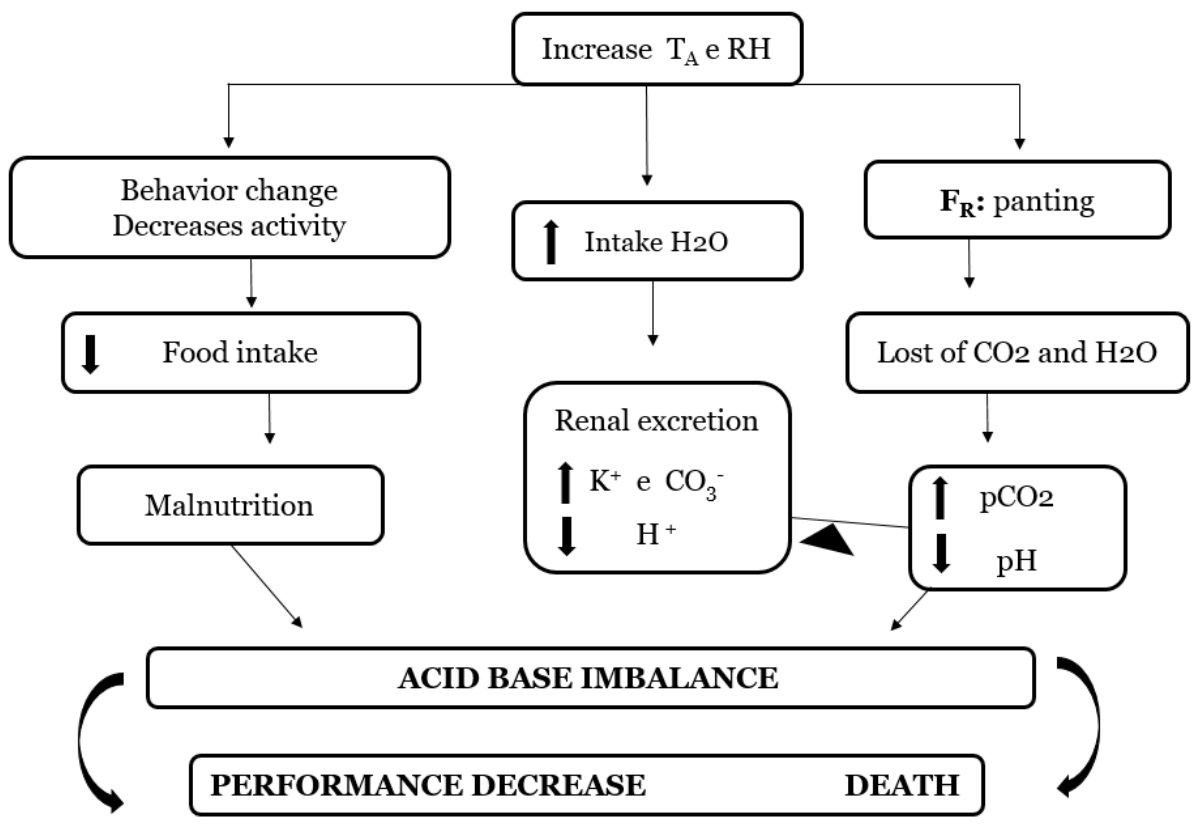

Figure 1 Representative diagram of the physiological responses of birds to heat stress. Source: Borges et al (2003).

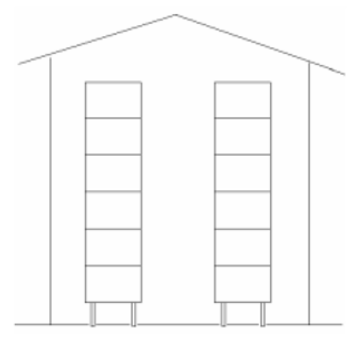

A

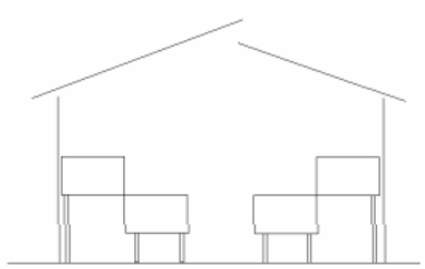

C

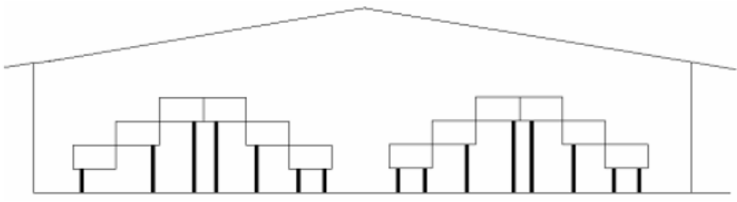

B

Figure 2 Layout of the cages in the conventional housing system for laying birds. A - vertical, B - Pyramidal, C and D 2-story pyramid. Source: Telatin Jr (2007). 


\section{Air conditioning of poultry houses}

The typology most used in Brazilian poultry facilities is open sheds with curtains for lateral closing (Mendes 2015). In this type of installation, ventilation occurs naturally and is controlled only by opening or closing curtains according to the temperature inside the installation.

Although natural ventilation is quite viable, it does not always allow air quality control, adequate oxygen levels, elimination of harmful gases (ammonia and $\mathrm{CO}_{2}$ ), and moisture and odors control (Baêta and Souza 2010).

Ventilation intensity is essential for comfortable facilities that use natural ventilation once low-speed winds lead to high-temperature zones inside the aviaries. Therefore, mechanical ventilation is necessary to meet the demands. One of the main advantages of using mechanical ventilation is homogeneous air distribution.

Negative pressure ventilation in tunnel mode is widespread in broiler production in Brazil. For laying birds, this type of longitudinal ventilation creates a gradient of up to $6{ }^{\circ} \mathrm{C}$ along the aviary and an even better temperature inside the shed. In addition, birds are housed at different levels concerning the floor due to the cages arrangement (Silva et al 2013). Negative pressure ventilation has a smaller interior amplitude when compared to natural ventilation, except for cages positioned near the east and west faces of the naturally ventilated aviary. Moreover, the temperatures inside the cages are significantly different from the temperatures in the hallways of the warehouses (Mendes 2015).

Mechanical ventilation is achieved by negative pressure or positive pressure. Negative pressure consists of removing air through exhaust fans, while positive pressure consists of forcing air into the installation (Nascimento et al 2011). Ruzal et al (2011), evaluated the effect of ventilation on egg production and quality. Their results showed that birds exposed to high temperatures reduced production but recovered production when exposed to adequate ventilation.

\section{Final Considerations}

The Brazilian poultry industry had an expressive growth in the last decades, mainly concerning genetics and nutrition. However, thermal comfort in poultry houses is needed to achieve poultry's maximum productive potential.

The producers have already assimilated such concern, who started to invest in upgrading poultry sheds and installing negative pressure ventilation systems in tunnel mode. The thermal efficiency and its distribution in the different cage levels of this ventilation system is slightly known; therefore, further investigations on this subject to find such information are encouraged.

\section{Conflict of Interest}

The authors have no conflicts of interest related to the present review.

\section{Funding}

This research did not receive any financial support.

\section{References}

Abbas G, Mahmood S, Haq A, Nawaz H (2019) effect of dietary inclusion of sodium bicarbonate on blood profile of caged layers during summer. Pakistan Journal of Agricultural Sciences. doi: 10.21162/PAKJAS/17.5014

Andrade RR (2017) Determinação da faixa de conforto térmico para galinhas poedeiras na fase inicial de criação. Dissertation, Universidade Federal de Viçosa.

Avicultura Industrial (2016) AveSui: Brasil é sétimo maior produtor mundial de ovos 2016. https://www.aviculturaindustrial.com.br/imprensa/brasil-esetimo-maior-produtor-mundial-de-ovos/20171113-144114-a215. Access on: November 1, 2019.

Baêta FC, Souza CF (2010) Ambiência em edificações rurais: conforto animal. Editora UFV, Viçosa.

Barbosa Filho JAD, Silva IJO, Silva MAN, Silva CJ (2007) Avaliação dos comportamentos de aves poedeiras utilizando sequência de imagens. Engenharia Agrícola. 27: 93-99.

Bilal RM, Hassan F, Farag MR, Nasir TA, Ragni M, Mahgoub HAM, Alagawany $M$ (2021) Thermal stress and high stocking densities in poultry farms: Potential effects and mitigation strategies. Journal of Thermal Biology. doi: doi.org/10.1016/j.jtherbio.2021.102944

Borges SA, Maiorka A, Silva AVF (2003) Fisiologia do estresse calórico e a utilização de eletrólitos em frangos de corte. Ciência Rural 33:975-981.

Castilho VAR, Garcia RG, Lima ND, Nunes KC, Caldara FR, Nääs IA, Barreto B, Jacob FG (2015) Bem-estar de Galinhas Poedeiras em Diferentes Densidades de Alojamento. Revista Brasileira de Engenharia de Biossistemas. 9:122-131.

Chen Z, Wang H, lonita C, Luo F, Jiang X (2015) Effects of chicken litter storage time and ammonia content on thermal resistance of desiccation-adapted Salmonella spp. Applied Environmental Microbiology 81:6883-6889.

Coelho DJR (2018) Ambiente térmico e aéreo de aviários sólidos de frangos de corte acondicionados artificialmente para condições climáticas do Brasil e Portugal. Thesis. Universidade Federal de Viçosa.

El-Kholy MS, El-Hindawy MM, Alagawany M, Abd El-Hack ME, El-Sayed SAA (2017) Dietary supplementation of chromium can alleviate negative impacts of heat stress on performance, carcass yield, and some blood hematology and chemistry indices of growing Japanese quail. Biological Trace Element Research doi: 10.1007/s12011-017-0936-z.

Farag MR, Alagawany M (2018) Physiological alterations of poultry to the high environmental temperature. Journal Thermal of Biology 76:101-106.

He S, Li S, Arowolo MA, Yu Q, Chen F, Hu R, He J (2019) Effect of resveratrol on growth performance, rectal temperature and serum parameters of yellow-feather broilers under heat stress. Animal Science Journal. doi: doi.org/10.1111/asj.13161

Hu Y, Cheng H, Tao S (2017) Environmental and human health challenges of industrial livestock and poultry farming in China and their mitigation. Environment International. doi: doi.org/10.1016/j.envint.2017.07.003

Huang S (2017) Upregulation of TLR4 mRNA Expression Levels in Broiler Chickens under Acute Heat Stress. Brazilian Journal Poultry Science. doi: doi.org/10.1590/1806-9061-2016-0344

Humane Society International - HIS (2014) As superlotadas gaiolas em bateria: A vida das galinhas poedeiras no Brasil. http://www.hsi.org/portuguese/issues/gaiolas_de_bateria.html. Access on: April 30, 2014

Mascarenhas NMH, Costa ANL, Pereira MLL, Caldas ACA, Batista LF, Andrade ELG (2018) Thermal conditioning in the broiler production: challenges and possibilities. Journal of Animal Behavour and Biometeorology 6:52-55

Mendes MASA (2015) Caracterização do ambiente térmico de aviários de postura, em sistemas verticais, ventilados naturalmente e por pressão negativa em modo túnel. Thesis, Universidade Federal de Viçosa.

Morais FTL, Lopes Neto JP, Santos AM, Leite PG, Cavalcanti RG (2020) Conforto térmico e desempenho de poedeiras na fase inicial. Energia na agricultura. doi: doi.org/10.17224/EnergAgric.2020v35n3p388-394

Nascimento GR, Pereira DF, Näas IA, Rodrigues LHA (2011) Índice fuzzy de conforto térmico para frangos de corte. Engenharia Agrícola 31:219-229. 
Nazareno AC, Pandorfi H, Almeida GLP, Giongo PR, Pedrosa EMR, Guiselini C (2009) Avaliação do conforto térmico e desempenho de frangos de corte sob regime de criação diferenciado. Revista Brasileira de Engenharia Agrícola e Ambiental 13:802-808.

Pereira DF, Batista ES, Sanches FT (2013) Comportamento de poedeiras criadas a diferentes densidades e tamanhos de grupo em ambiente enriquecido. Pesquisa Agropecuária Brasileira 48:682-688.

Reis JT, Freitas ES (2020) Avaliação dos índices zootécnicos de frangos de corte criados em diferentes instalações. Arquivos Brasileiros de Medicina Veterinária FAG 3:8-17.

Ruzal M, Shinder D, Malka I, Yahav S (2011) Ventilation plays an important role in hens' egg production at high ambient temperature. Poultry Science doi: $10.3382 /$ ps.2010-00993.

Saeed M, Abbas G, Alagawany M, Kamboh AA, El-Hack MEA, Khafaga AF, Chao $S$ (2019) Heat stress management in poultry farms: A comprehensive overview. Journal of Thermal Biology 84:414-425.

Scanes CG (2015) Sturkies Avian Physiology. Elsevier, London.
Silva EG, Santos AC, Ferreira CLS, Sousa JPL, Rocha JML, Silveira Jr O (2013) Variabilidade espacial das características ambientais e peso de frangos de corte em galpão de ventilação negativa. Revista Brasileira de Saúde e Produção Animal 14: 132-141.

Silva LF, Menegali I, Rippel DN, Silva EPF, Ferreira F (2017) Bioclimatic indexes in laying poultry on the different productive phases. Caderno de Ciências Agrárias 9:31-37.

Tan, CL, Knight ZA (2018) Regulation of body temperature by nervous system. Neuron doi: 10.1016/j.neuron.2018.02.022.

Telatin Jr A (2007) Caracterização tipológica e bioclimática da avicultura de postura no Estado de São Paulo-um estudo de caso. Dissertation, Universidade de São Paulo.

Yousaf A, Jabbar A, Rajput N, Memon A, Shahnawaz R, Mukhtar N, Farooq Abbas M, Khalil R (2019) Effect of Environmental Heat Stress on Performance and Carcass Yield of Broiler Chicks. Word's Veterinary Journal. doi: doi.org/10.36380/scil.2019.wvj4 